\title{
Restriction Pattern Analysis by High-performance Liquid Chromatography of PCR-amplified 16S rDNA Fragments from Scum-forming Bacteria in Activated Sludge
}

\author{
AKIRA Hiraishi ${ }^{1,2 *}$, Yong KooK ShIN $^{2 * *}$ and Jun-ICHI TAKeUCHI ${ }^{3}$ \\ ${ }^{1}$ Department of Ecological Engineering, Toyohashi University of Technology, Toyohashi 441, Japan \\ 2 Laboratory of Environmental Biotechnology, Konishi Co., Tokyo 130, Japan \\ ${ }^{3}$ Kosuge Sewage Treatment Plant, Sewege Bureau of Tokyo, Tokyo 124, Japan
}

(Received March 26, 1997-Accepted May 31, 1997)

\begin{abstract}
High-performance liquid chromatography (HPLC) with an anion-exchange nonporous column was used to analyze restriction fragment length polymorphism (RFLP) of the 16S ribosomal DNA (rDNA) of scum-forming actinomycetes found in three different activated sludge plants. 16S rDNA fragments from washed scum samples were amplified by PCR and cloned into plasmid vectors. The 16S rDNA inserts in the plasmids were reamplified in vitro, cut with restriction endonucleases, and separated directly by HPLC. Compared to conventional agarose electrophoresis, the HPLC system used allowed better separation of fragments up to $500 \mathrm{bp}$. The HPLC-RFLP patterns of the scum clones were compared with those of PCR-amplified 16S rDNAs from authentic strains and with computerpredicted restriction patterns of the available 16S rDNA data on the actinomycetes. 16S rDNA-RFLP comparisons indicated that the predominat scum-forming bacteria were Gordona amarae in two activated sludge plants and Rhodococcus sp. in the remaining one. These findings agreed well with results of lipoquinone profiling of the scum performed concurrently. The results of this study indicated that a combination of 16S rDNA-RFLP analysis and quinone profiling should provide a more powerful non-cultivating tool for the identification of scum-forming bacteria in activated sludge.
\end{abstract}

Key words: PCR, RFLP, 16S rDNA, Scum-forming bacteria, HPLC

\section{Introduction}

The production of abnormal foam or scum on the aeration tanks of activated sludge plants, which causes a serious operating problem, was first reported in $1969^{1)}$. Lechevalier and Lechevalier ${ }^{30)}$ isolated novel nocardioform actinomycetes from scumming sludge

* Corresponding author; Tel: 0532-44-6913, Fax: 0532-44-6929, E-mail: hiraishi@eco.tut.ac.jp.

** Present address: Korean Collection for Type Cultures, Genetic Resources Center, Korea Research Institute of Bioscience \& Biotechnology, Korea Institute of Science \& Technology, Taejon 305-333, Korea. and proposed a new species for them with the name Nocardia amarae in 1974. Since then, this species has been and is still regarded as the predominant scum-forming organism in activated sludge plants ${ }^{10,39,40,46)}$. In addition to this organism, however, some other members of actinomycetes including Rhodococcus species" ${ }^{25,31,35)}$, Nocardia pinensis ${ }^{4)}$, and "Microthrix parvicella" "3,16) have been found as scum-forming agents. Cases of scum formation in Japan have been reviewed as to their biological and operational aspects by Takeuchi ${ }^{4-51)}$ and Fujita ${ }^{12)}$.

In recent years, molecular phylogenetic studies based on 16S rRNA sequences have led to the taxonomic revision of actinomycetes, including those recognized 
as scum formers. The genus Gordona was revived to accommodate some scum-forming species of rhodococci ${ }^{48)}$. N. amarae has been transferred to the genus Gordona as Gordona amarae ${ }^{13,26,42)}$. Moreover, the scum-forming filamentous bacterium "Microthrix parvicella", which grows with great difficulty in cultures from sludge, was proposed to be classified with the name "Candidatus Microthrix parvicella"').

The accurate and rapid determination of the kinds of actinomycetes responsible for sludge scumming is an important first step in the understanding and possible control of the separation problem in wastewater treatment. In previous studies attempts were made to identify scum-forming actinomycetes on the basis of their morphological, physiological, and chemotaxonomic characteristics ${ }^{4,30,31)}$. However, since these phenotypic approaches require isolation and cultivation of pure cultures, they are tedious and time-consuming for practical and routine use. An identification system for this purpose needs to be as rapid and simple as possible without sacrificing reliability, and preferably should not require isolation and cultivation. In this respect, a molecular analysis of a clone library of 16S rRNA genes amplified from activated sludge ${ }^{7,47)}$ attracts interest.

We have focused our attention toward the fact that restriction fragment length polymorphism (RFLP) of PCR-amplified 16S rDNA has increasingly been used for rapid identification and classification of a wide variety of microorganisms, including clostridia ${ }^{15}$, mycoplasmas ${ }^{45)}$, rhizobia ${ }^{28)}$, phototrophic purple bacteria $^{21)}$, nonphototrophic proteobacteria ${ }^{37,53,54)}$, and some other microbes ${ }^{19,41)}$. Also, RFLP analysis of PCR clone libraries of 16S rDNA from mixed microbial populations has been found to provide information of value for the assessment of the community structure $^{19,36)}$. Fortunately, great numbers of $16 \mathrm{~S}$ rDNA sequence data, including those on scum-forming actinomycetes, are now available from the databases, and this situation makes it possible to compare experimental 16S rDNA-RFLP data with computerpredicted RFLP patterns of the available $16 \mathrm{~S}$ rDNA sequences.

While the conventional technique for the analysis of
16S rDNA-RFLP profiles involves the use of acrylamide or agarose gel electrophoresis, we attempted to use high-performance liquid chromatography (HPLC) with an anion-exchange nonporous column for this purpose to increase resolution of fragment patterns. This technique has been successfully used to separate PCR products ${ }^{2,55)}$. The present study describes the applicability of the PCR cloning and HPLC-RFLP analysis of 16S rDNA for the rapid identification of scum-forming bacteria in activated sludge without the need for cultivation. A combined use of 16S rDNA-RFLP analysis and lipoquinone profiling ${ }^{17,18,23)}$ as a valuable tool for in situ identification of scum-forming actinomycetes is also discussed.

\section{Materials and Methods}

\section{Scum samples}

Scum samples were collected from the surface of aeration tanks in three different activated sludge plants in Tokyo and Kanagawa Prefecture in 1993, and designated scum A, B, and C, respectively. These samples were taken in sterile polyethylene bottles and preserved in an insulated cooler during transportation to the laboratory. The sludge-scum mixture was introduced into a $200 \mathrm{ml}$ graduated glass cylinder and settled for $30 \mathrm{~min}$ at room temperature. The resultant floating scum was collected by a pipette from the top of the cylinder, resuspended in autoclaved saline $(0.9 \%)$, and settled again in a glass cylinder for 30 min. The scum was then collected and the procedure repeated. The scum thus collected was washed twice with EDTA-saline $\left(0.15 \mathrm{M} \mathrm{Na}_{2}\right.$ EDTA $+0.15 \mathrm{M} \mathrm{NaCl}$, $\mathrm{pH}$ 8.5), pelleted by centrifugation, and stored at $-20^{\circ} \mathrm{C}$ until analysis.

\section{Bacterial strains and cultivation}

The strains of scum-forming bacteria tested in this study were the type strains of Gordona amarae, Gordona bronchialis, Grodona rubropertinctus, Gordona sputi, and Gordona terrae (Table 1), all of which were obtained from the Japan Collection of Microorganisms (JCM), RIKEN, Wako. For cultivation of these organisms, $\mathrm{PBY}$ medium ${ }^{20)}$ supplemented with $1 \%$ glucose was used. Cells were grown aerobically on a recip- 
Table 1. Bacterial strains tested and the sources of 16S rDNA sequences used for RFLP analysis

\begin{tabular}{|c|c|c|c|}
\hline Species & Strain used $^{\mathrm{a}}$ & Other designation & $\begin{array}{c}\text { Source of } \\
\text { sequence information } \\
\text { (accession number) }\end{array}$ \\
\hline Gordona aichiensis & & & $\mathrm{X} 80633$ \\
\hline Gordona amarae & $\mathrm{JCM} 3171^{\mathrm{T}}$ & DSM 43392 & X80635 \\
\hline Gordona bronchialis & $\mathrm{JCM} 3198^{\mathrm{T}}$ & DSM 43247 & X79287 \\
\hline Gordona hydrophobica & & & X87340 \\
\hline Gordona rubropertinctus & $\mathrm{JCM} 3204^{\mathrm{T}}$ & DSM 43197 & $\mathrm{X} 80632$ \\
\hline Gordona sputi & $\mathrm{JCM} 3228^{\mathrm{T}}$ & ATCC 29627 & X80634 \\
\hline Gordona terrae & $\mathrm{JCM} 3206^{\mathrm{T}}$ & DSM 43249 & X79287 \\
\hline Rhodococcus coprophilus & & & X80626 \\
\hline Rhodococcus equi & & & X80614 \\
\hline Rhodococcus rhodochrous & & & X79288 \\
\hline Rhodococcus ruber & & & X80625 \\
\hline
\end{tabular}

a Superscript $\mathrm{T}=$ type strain.

rocal shaker at $30^{\circ} \mathrm{C}$ and harvested by centrifugation at the mid-exponential phase of growth. The cell pellet was washed twice with EDTA-saline, resuspended in $200 \mu \mathrm{l}$ of pure water prepared with the Millipore MilliQ system, and stored at $-20^{\circ} \mathrm{C}$ until used.

\section{PCR amplification from cultures}

Cell lysates from stocked cell suspensions were prepared for PCR use as described previously ${ }^{19,22)}$. Briefly, the cell suspension was thawed at room temperature and sonicated on ice for $30 \mathrm{sec}$ with $2 \mathrm{sec}$ intermittent bursts with an Ohtake soniprobe $(20 \mathrm{kHz}$ : output power, $100 \mathrm{~W})$. The sonicated suspension was mixed with BL buffer ( $40 \mathrm{mM}$ Tris, $1 \%$ Tween 20 , $0.5 \%$ Nonidet P-40, $1 \mathrm{mM}$ EDTA, $\mathrm{pH}$ 8.0) and proteinase $\mathrm{K}$ solution $(1 \mathrm{mg} / \mathrm{ml})$ at a volume ratio of $4: 5$ : 1 , incubated at $60^{\circ} \mathrm{C}$ for $30 \mathrm{~min}$ and then at $95^{\circ} \mathrm{C}$ for 5 $\mathrm{min}$, and centrifuged for $10 \mathrm{~min}$ to remove unbroken cells and large debris. The resultant crude lysate was appropriately diluted with MilliQ water to give an absorbance at $260 \mathrm{~nm}\left(A_{260}\right)$ of 15 , and $1 \mu \mathrm{l}$ of this dilute lysate was used as the source of template DNA for PCR in a $100 \mu$ reaction. 16S rDNA fragments which corresponded to positions 8 to 1510 of Escherichia coli $16 \mathrm{SRNA}^{8)}$ were amplified by PCR directly from the crude lysate with a pair set of eubacterial universal primers, 27f and $1492 \mathrm{r}^{29}$. PCR products were treated with a chloroform-isoamyl alcohol mixture, precipitated with ammonium acetate and ethanol, and purified by the polyethylene precipitation method ${ }^{19,27)}$. Detailed information on the PCR procedures used has been given elsewhere ${ }^{19,22)}$. The 16S rDNAs which had been amplified and purified previously from the phototrophic bacteria ${ }^{21)}$ were used as the reference PCR products for electrophoresis and HPLC experiments.

\section{Preparation of PCR templates from scum}

The bulk DNA of scum was purified in the following manner. The stocked scum sample (ca. $2 \mathrm{~g}$ wet wt) was thawed at room temperature and resuspended in sucrose-lysis buffer ( $10 \%$ sucrose, $0.7 \mathrm{M} \mathrm{NaCl}, 40 \mathrm{mM}$ $\mathrm{Na}_{2}$ EDTA, $50 \mathrm{mM}$ Tris- $\mathrm{HCl}, \mathrm{pH} 8.5$ ) to a total volume of $10 \mathrm{ml}$, to which lysozyme $(1 \mathrm{mg} / \mathrm{ml})$ was then added. This suspension was subjected to three cycles of disruption with a French pressure cell at 20,000 p.s. i. The disrupted sample was treated with proteinase $\mathrm{K}(0.1 \mathrm{mg} / \mathrm{ml})$ at $60^{\circ} \mathrm{C}$ for $30 \mathrm{~min}$ and then with $1 \%$ sodium dodecyl sulfate at $60^{\circ} \mathrm{C}$ for $30 \mathrm{~min}$. The slurry was further treated with $1 \%$ hexadecyltrimethyl ammonium bromide at $60^{\circ} \mathrm{C}$ for $30 \mathrm{~min}$ to remove polysaccharides and residual proteins as precipitates. The digested samples was treated with phenol-chloroform-isoamyl alcohol (25: 24: 1, v/v) with shaking and centrifuged. The crude DNA in the resultant aqueous layer was obtained by ethanol pre- 
cipitation and centrifugation and was subjected to a standard purification procedure consisting of RNase digestion, chloroform-isoamyl alcohol treatment, and ethanol precipitation ${ }^{34)}$. The DNA sample was further purified by cesium chloride gradient ultracentrifugation at $50,000 \mathrm{rpm}$ for $20 \mathrm{~h}$ with a Beckman VTi 65 rotor. DNA was visualized by ethidium bromide fluorescence and withdrawn with a hypodermic syringe. The DNA was treated with water-saturated butanol and then subjected to dialysis against TE buffer (10 $\mathrm{mM}$ Tris-HCl, $1 \mathrm{mM} \mathrm{Na}{ }_{2}$ EDTA, $\mathrm{pH}$ 7.8) to remove ethidium bromide and cesium chloride, respectively. All purified DNAs were dissolved in TE buffer. In some cases, crude lysates were prepared from the scum. The sample was thawed at room temperature, resuspended in MilliQ water $(1: 3, \mathrm{w} / \mathrm{v})$, and then sonicated on ice for $30 \mathrm{sec}$ with $2 \mathrm{sec}$ intermittent bursts as noted above. The sonicated suspension was mixed with an equal volume of BL buffer and subjected to enzyme digestion, heat treatment, and centrifugation as described above for pure cultures. The resultant crude lysate was appropriately diluted with MilliQ water and used directly for PCR.

\section{PCR amplification and cloning from scum DNA}

PCR experiments were performed with either the crude lysate or $10 \mathrm{ng}$ of purified DNA as the template and the pair set of the universal primers as noted above. PCR products from the crude lysate were purified by the PEG precipitation method and used directly for endonuclease digestion. PCR fragments from the bulk DNA were purified by agarose electrophoresis and glass binding ${ }^{19)}$ and cloned by the T-A cloning method $^{24,33)}$ with a pT7Blue T-Vector kit (Novagen, Madison, USA) or with a SureClone Ligation kit (Pharmacia, Upsala, Sweden). Transformation of $E$. coli competent cells was carried out according to a standard manual of molecular cloning ${ }^{44)}$. Plasmid DNA was isolated and purified by using a Pharmacia FlexiPrep kit according to the manufacturer's instructions. The cloned 16S rDNA in the plasmids was reamplified by PCR and purified by PEG precipitation as described above. In all cases, PEG-precipitated 16S rDNA samples were redissolved in $20 \mu$ of pure water for RFLP analysis.

\section{RFLP analysis}

Previous studies have implied that a combined use of tandem tetrameric restriction endonuclease, such as HaeIII, HhaI, and MspI, is suitable for RFLP analysis of PCR-amplified 16S rDNA of ca. $1.5 \mathrm{~kb}$ for the identification of strains at the species level ${ }^{19,21)}$. This was the also the case in the classification of the 16S rDNA clones from mixed populations in the environments ${ }^{36}$. In this study, therefore, we used these restriction enzymes and another enzyme, SmaI, all of which we purchased from Takara Shuzo Co. PEG-purified PCR products were cut independently with four restriction endonucleases according to the manufacturer's instructions, and separated directly by HPLC. The HPLC system used in this study consisted of a Toso CCPM-2 solvent delivery module, a TSKgel DEAENPR column ( $4.6 \mathrm{~mm}$ [internal diameter] $\times 3.5 \mathrm{~cm})$, a Toso UV-8020 detector, and an autosampler, Toso AS8020. Ten $\mu$ l of sample was injected, eluted at $25^{\circ} \mathrm{C}$ and a flow rate of $1 \mathrm{ml} / \mathrm{min}$ in a linear gradient of 0 to $0.5 \mathrm{M} \mathrm{NaCl}$ in $20 \mathrm{mM}$ Tris-HCl buffer (pH 8.0), and monitored at $260 \mathrm{~nm}$. To estimate the size of fragments, 100 bp ladder marker (Pharmacia) and $\phi 174$ RF I DNA (Takara Shuzo) were used as the external standards. For comparison, digested fragments were also detected using a Mupid mini-gel electrophoresis apparatus (Advantec Co., Tokyo, Japan) with 2\% MetaPhor agarose gels (FMC BioProducts, Rockland, ME, USA) and $1 \mathrm{X}$ Tris-boric acid-EDTA buffer, and by staining with ethidium bromide as described ${ }^{17)}$.

\section{DNA sequencing}

Cloned 16S rDNA was partially sequenced by the linear PCR sequencing method with SequiTherm Long Read cycle sequencing kit (Epicentre) and fluorescent primer r 1L (5'-GTATTACCGCGGCTGCTGG-3' $)^{22)}$. This reaction covered a nucleotide stretch of ca. $500 \mathrm{bp}$ between positions 8 to 510 in the $E$. coli numbering system. The reaction products were analyzed with a Pharmacia ALF DNA sequencer. 


\section{Data compiling and phylogenetic analysis}

The available 16S rDNA sequence information was obtained from the Ribosomal Database Project ${ }^{32}$ ) (see Table 1), and RFLP patterns of the reference $16 \mathrm{~S}$ rDNAs were analyzed with the GENETYX-MAC personal computer program (Software Developing Co., Tokyo, Japan). For phylogenetic analysis of RFLP data, all fragments of different sizes obtained with the four enzymes were listed sequentially, and single fragments coded as $\mathrm{S}$, duplicate fragments as $\mathrm{V}$, triplicate fragments as $\mathrm{W}$, fragments absent as $\mathrm{T}$. Multiple alignment of these sequences, calculation of percentage divergence, and construction of neighbor-joining phylogenetic trees ${ }^{43)}$ were performed with CLUSTAL $\mathrm{W}^{52)}$. A phylogenetic tree based on the available $16 \mathrm{~S}$ rRNA sequences of the scum-forming actinomycetes was also constructed with this program. Drawing of the tree was performed with the TreeView program ${ }^{38)}$.

\section{Quinone analysis}

Quinones in scum samples were extracted with an organic solvent mixture, fractionated with a Millipore Sep-Pak silica column, and identified by spectrochromatography with external standards as described ${ }^{23}$.

\section{Results}

\section{PCR amplification and cloning}

Using all the test strains of the Gordona species, we performed preliminary experiments to make a protocol for the preparation of crude lysates to be used as PCR templates, because the protocol previously designed was only for Gram-negative bacteria ${ }^{22)}$. In fact, we sometimes failed to amplify 16S rDNA from the Gordona cells with this protocol. This problem was solved in most cases by introducing sonic treatment (30 sec with $2 \mathrm{sec}$ intermittent bursts) prior to the protease digestion in the preparation of cell lysates, as shown in Materials and Methods. This new version of the protocol was also applicable to the direct amplification of 16S rDNA from the lysate of the scum samples. If the amplification was unsuccessful even with this modified procedure, lysate 50 -fold more diluted than indicated in the formula was used for
PCR, resulting in detection of appreciable amounts of PCR products. On the other hand, all scum DNA samples purified generated high PCR signals constantly as long as $50 \mathrm{ng}$ of the DNA was used as the template.

In cloning experiments, we found significant differences in the efficiency of transformation between the two cloning kits used. In all cases, the efficiency of transformation by the TA cloning technique was low, whereas the use of a SureClone Ligation kit with a blunt-ended vector resulted in higher efficiency $(2-5 \times$ $10^{7}$ transformants per $\mu \mathrm{g}$ of plasmid). Therefore, the 16S rDNA clone libraries from all scum samples were made by the latter method. Inserts of the plasmids were checked by cutting them with EcoR I and BamH I and detecting by agarose gel electrophoresis. As a result, 60 to $70 \%$ of the recombinants randomly selected contained a 16S rDNA insert of ca. $1.5 \mathrm{bp}$.

\section{Preliminary experiments for HPLC conditions}

Using endonuclease digests of the PCR-amplified 16S rDNA from the phototrophic bacteria, we attempted to determine favorable HPLC conditions that give high resolution of DNA fragments but can end a run as soon as possible (e.g., within $20 \mathrm{~min}$ ), and employed the analytical conditions described in the Methods. Figure 1 shows an example of the HPLC analysis applied to the HaeIII digest of the 16S rDNA from Rhodobacter azotoformans, which includes 34, $39,66,85,127,154,158,279$, and 452 bp fragments as predicted with the computer program and also reported previously ${ }^{21}$. The RFLP pattern predicted for $R$. azotoformans 16S rDNA was supported fully by HPLC experiments. Of particular interest was the peak resolution between the 154 and $158 \mathrm{bp}$ fragments (indicated by an arrow in Fig. 1). These two fragments could not be separated from each other by MetaPhor agarose gel electrophoresis performed concurrently (data not shown).

These results suggest that the HPLC system is superior to conventional agarose gel electrophoresis in resolution. However, peak resolution of the HPLC system was lowered sharply with increasing size of DNA fragments. Minimum size differences with which DNA fragments of about 200 and 500 bp could be resolved at peak points were 5 and $15 \mathrm{bp}$, respective- 


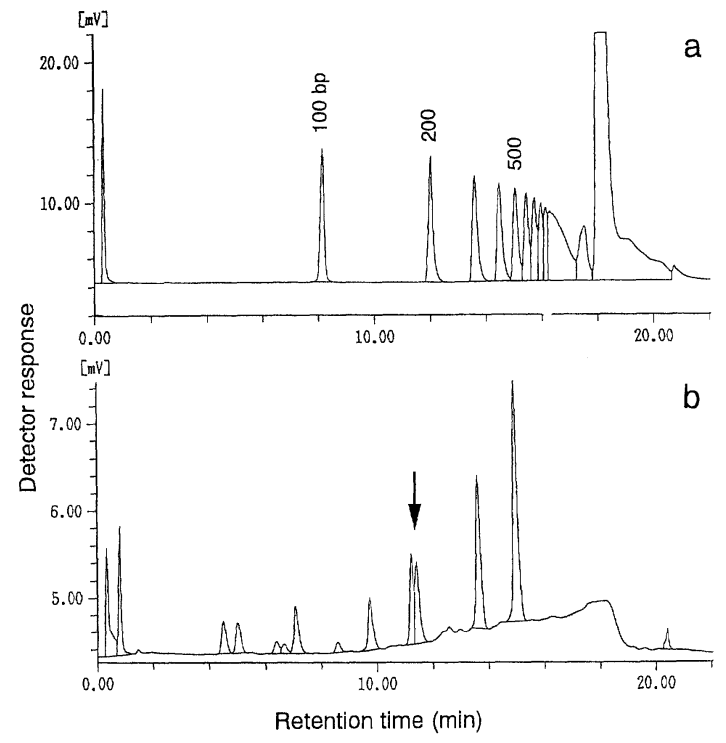

Fig. 1. HPLC elution profiles of a $100 \mathrm{bp}$ ladder marker (a) and HaeIII-digested fragments of PCR-amplified $16 \mathrm{~S}$ rDNA from Rhodobacter azotoformans (b).

ly. A combined use of the standard DNA fragments, $\phi \times 174$ HaeIII digest and 100 bp ladder markers, could cover a size range of 72 to $1,353 \mathrm{bp}$. With the power of resolution of the HPLC system used, however, accurate estimation of fragment size with the external standards was possible for fragments of up to $500 \mathrm{bp}$.

\section{RFLP and sequence analyses}

For each scum sample, 10 positive clones were chosen and subjected to the reamplification of $16 \mathrm{~S}$ rDNA inserts. As a result, the reamplification was successful in 8 clones from scum A (A1-A8), 6 clones from scum B (B1-B6), and 7 clones from scum $C$ (C1-C7). The reason for the failure to reamplify some 16S rDNA clones is unclear. For comparison, the 16S rDNA amplified directly from the crude lysates of the scum and the authentic strains of Gordona species was also amplified and tested. All these 16S rDNA samples were endonuclease-digested and directly analyzed by HPLC. Figure 2 shows examples of HPLC patterns of the HaeIII-digested fragments of clones $\mathrm{A} 1$ and $\mathrm{B} 1$, which were thought to be derived from G. amarae and Rhodococcus sp., respectively,

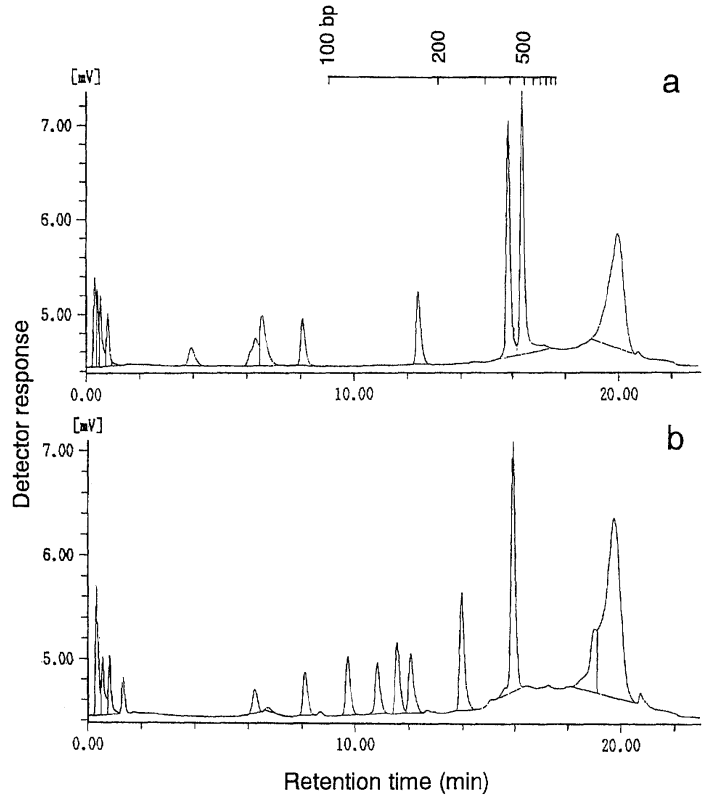

Fig. 2. HPLC elution profiles of HaellI-digested fragments of PCR-amplified 16S rDNA clones from the scum. (a), clone A1; (b), clone B1. A scale of fragment size estimated with a $100 \mathrm{bp}$ ladder marker is shown.

as described below.

The 16S rDNA-RFLP profiles of the scum clones and of all actinomycete species experimentally determined and computer-predicted are summarized in Table 2. All or almost clones obtained from the same plant gave identical RFLP patterns which could be identified as belonging to a member of the actinomycetes. The RFLP patterns of 6 clones from scum A (A1-A2, A4-A7) and 7 clones from scum C (C1-C7) were almost identical with those of $G$. amarae JCM 3171. The partial sequences of these clones also exhibited a similarity of more than $99 \%$ to the available $16 \mathrm{~S}$ rDNA sequence of $G$. amarae. On the other hand, the RFLP profiles of 5 clones from scum B (B1-B5) differed from those of any reference organisms, although the partial sequences of these clones were similar to those of members of the genus $R$ hodococcus with $R$. erythropolis as the closest relative ( $98 \%$ similarity). Unfortunately, exact RFLP patterns of $R$. erythropolis could not be predicted, because the available sequence information on this or- 
Table 2. 16S rDNA-RFLP patterns of major scum clones and species of the genera Gordona and Rhodococcus ${ }^{\mathrm{a}}$

\begin{tabular}{|c|c|c|c|c|c|c|c|c|c|c|c|c|c|c|}
\hline $\begin{array}{l}\text { Restriction enzyme } \\
\text { used and size (bp) } \\
\text { of fragments }{ }^{\mathrm{b}}\end{array}$ & $\begin{array}{l}\text { Clones } \\
\text { A1-A3, } \\
\text { A4-A7 }\end{array}$ & $\begin{array}{l}\text { Clones } \\
\text { B1-B4 }\end{array}$ & $\begin{array}{l}\text { Clones } \\
\text { C1-C7 }\end{array}$ & $\begin{array}{l}\text { G. } \\
\text { aichi- } \\
\text { ensis }\end{array}$ & $\begin{array}{c}G . \\
\text { amarae }\end{array}$ & $\begin{array}{l}G . \\
\text { bron- } \\
\text { chialis }\end{array}$ & $\begin{array}{c}\text { G. } \\
\text { hydro- } \\
\text { phobica }\end{array}$ & $\begin{array}{l}G . \\
\text { rubroper- } \\
\text { tinctus }\end{array}$ & $\begin{array}{c}G . \\
\text { sputi }\end{array}$ & $\begin{array}{c}G . \\
\text { terrae }\end{array}$ & $\begin{array}{l}R . \\
\text { copro- } \\
\text { philus }\end{array}$ & $\begin{array}{c}R . \\
\text { equi }\end{array}$ & $\begin{array}{l}R . \\
\text { rhodo- } \\
\text { chrous }\end{array}$ & $\begin{array}{l}R . \\
\text { ruber }\end{array}$ \\
\hline \multicolumn{15}{|l|}{ HaeIII (GGCC) } \\
\hline $458-460$ & + & - & + & + & + & {$[+]$} & + & + & + & + & $+\mathrm{d}$ & - & - & - \\
\hline 391 & + & + & + & + & + & + & + & + & + & + & - & + & + & + \\
\hline 353 & - & - & - & - & - & - & - & - & - & - & - & - & + & - \\
\hline 312 & - & - & - & - & - & $(+)$ & - & - & - & - & - & - & - & + \\
\hline $227-228$ & - & + & - & - & - & - & - & - & - & - & + & - & + & - \\
\hline $218-221$ & - & - & - & - & $(+)$ & - & - & - & - & - & - & + & - & + \\
\hline $151-155$ & + & - & + & + & {$[+]$} & + & + & + & + & + & - & + & - & - \\
\hline 146 & - & + & - & - & - & + & - & - & - & - & - & + & - & + \\
\hline 135 & - & + & - & - & - & - & - & - & - & - & - & - & - & - \\
\hline 126 & - & + & - & - & - & - & - & - & - & - & - & - & - & - \\
\hline 105 & - & + & - & - & - & - & - & - & - & - & - & - & + & - \\
\hline 93 & - & - & - & - & - & - & - & - & - & - & - & + & - & - \\
\hline 85 & + & + & + & + & + & + & + & + & + & + & + & + & + & + \\
\hline \multicolumn{15}{|l|}{ HhaI (GCGC) } \\
\hline 667 & - & - & - & - & - & - & - & - & - & - & - & + & - & - \\
\hline $440-444$ & - & + & - & - & - & - & - & - & - & - & + & - & - & - \\
\hline $406-408$ & + & + & + & + & +1 & {$[+](+d)$} & + & $+d$ & $+\mathrm{d}$ & $+\mathrm{d}$ & + & - & + & + \\
\hline 381 & - & - & - & - & - & - & - & - & - & - & - & + & - & - \\
\hline $366-370$ & + & - & + & + & + & + & + & + & + & {$[+]$} & - & - & + & + \\
\hline $295-300$ & + & - & + & - & + & + & + & + & - & + & - & - & + & - \\
\hline $221-230$ & + & $+\mathrm{d}$ & + & + & + & - & + & {$[+]$} & + & + & $+\mathrm{d}$ & + & + & $+\mathrm{d}$ \\
\hline 142 & - & - & - & - & - & - & - & - & - & $(+)$ & - & - & - & - \\
\hline 137 & + & - & + & - & + & - & + & - & - & - & - & - & - & - \\
\hline 125 & - & + & - & - & - & - & - & - & - & - & + & + & + & + \\
\hline \multicolumn{15}{|l|}{ MspI (CCGG) } \\
\hline 473 & - & - & - & - & - & - & - & - & + & - & - & - & - & - \\
\hline 422 & - & - & + & + & - & + & + & + & + & + & - & - & - & - \\
\hline $309-310$ & + & - & + & + & + & + & + & + & - & + & - & - & - & - \\
\hline $284-291$ & + & + & + & - & + & - & - & - & - & - & + & + & + & + \\
\hline 223 & + & - & + & + & + & - & + & + & + & + & - & - & - & - \\
\hline 176 & - & + & - & - & - & - & - & - & - & - & + & + & + & + \\
\hline $159-164$ & $+d$ & $+d$ & $+d$ & $+d$ & $+d$ & $+d$ & $+\mathrm{d}$ & $+\mathrm{d}$ & + & $+\mathrm{d}$ & $+\mathrm{t}$ & $+\mathrm{t}$ & $+\mathrm{d}$ & $+\mathrm{t}$ \\
\hline $130-131$ & + & $+d$ & + & - & + & - & - & - & - & - & + & - & + & - \\
\hline 125 & - & - & - & - & - & - & - & - & - & - & - & - & + & - \\
\hline $115-116$ & - & - & - & - & - & - & - & - & - & - & + & + & + & - \\
\hline 93 & - & + & - & - & - & + & - & - & - & - & + & + & + & + \\
\hline 82 & - & + & - & - & - & + & - & - & - & - & - & + & - & + \\
\hline \multicolumn{15}{|l|}{ SmaI (CCCGGG) } \\
\hline $1353-1355$ & + & + & + & + & + & + & + & + & + & + & + & + & + & + \\
\hline 130 & + & + & + & + & + & + & + & + & + & + & + & + & + & + \\
\hline
\end{tabular}

a Symbols: + , fragment present; $+\mathrm{d}$, duplicate fragments present; $+\mathrm{t}$, triplicate fragments present; - , fragment absent; $(+)$, fragment positive as computer-predicted but not shown experimentally; $[+]$, fragment positive as shown experimentally but not computer-predicted.

b Fragment sizes ( $>80 \mathrm{bp}$ ) estimated based on HPLC analysis, computer-aided restriction analysis, or a combination of both. 
ganism was partial ( $<1370 \mathrm{bp}$ ). The RFLP patterns of the remaining clones, $\mathrm{A} 3, \mathrm{~A} 8$, and $\mathrm{B} 6$, were not of gram-positive origin (data not shown) and were indicative of the beta subclass of Proteobacteria in view of their sequences determined concurrently. The RFLP patterns of the 16 S rDNAs amplified directly from the scum lysates were identical with those of the major 16S rDNA clones from the same scum samples.

As shown in Table 2, there were some differences in RFLP patterns between our experimental data and computer-predicted data on some Gordona species including $G$. amarae. In addition to the $16 \mathrm{~S}$ rDNA sequence of the type strain of $G$. amarae used in this study (EMBL/DDBJ/GenBank accession number, $\mathrm{X} 80635)^{26)}$, sequence data on the same strain have been reported independently by two other groups ${ }^{13,42)}$. However, the data differ to some extent and give different restriction patterns. It may be necessary to reexam- ine the 16S rDNA sequence of the above-noted Gordona species.

\section{Phylogenetic analysis}

The phylogenetic implication of 16S rDNA-RFLP patterns was evaluated by comparing the dendrogram constructed on the basis of these patterns with the phylogenetic tree inferred from the 16S rDNA sequences themselves. Both trees were constructed by the neighbor-joining method, and the branching patterns of the trees was evaluated by bootstrapping ${ }^{11)}$. As shown in Fig. 3, the topography of both trees was similar, suggesting that the 16S rDNA-RFLP patterns have phylogenetic significance. In the RFLP-based tree, the major clones of scum $\mathrm{A}$ and scum $\mathrm{C}$ formed a cluster with $G$. amarae supported by a relatively high bootstrap value, whereas the major clones of scum B were grouped with $R$. coprophilus.


0.01

Fig. 3. Distance matrix trees showing phylogenetic relationships among scum-forming actinomycetes and related bacterial clones. (a), tree inferred from the 16S rDNA sequences (scale bar=one base substitution per 100 nucleotides); (b), tree based on the 16S rDNA-RFLP patterns (scale bar $=10 \%$ divergence). The $16 \mathrm{~S}$ rDNA sequence of Arthrobacter globiformis was used as an outgroup to root the trees. Both trees were constructed by the neighbor-joining method. 
Table 3. Quinone composition of raw and washed scum samples from three different activated sludge plants

\begin{tabular}{|c|c|c|c|c|c|c|}
\hline \multirow{3}{*}{$\begin{array}{l}\text { Quinone type } \\
\text { detected }\end{array}$} & \multicolumn{6}{|c|}{ Quinone composition (mol\%) } \\
\hline & \multicolumn{2}{|c|}{ Scum A } & \multicolumn{2}{|c|}{ Scum B } & \multicolumn{2}{|c|}{ Scum C } \\
\hline & Raw & Washed & Raw & Washed & Raw & Washed \\
\hline Ubiquinones & 47.5 & 11.7 & 52.8 & 13.3 & 48.4 & 8.3 \\
\hline $\mathrm{MK}-8\left(\mathrm{H}_{2}\right)$ & 4.9 & 8.4 & 24.2 & 62.2 & 6.2 & 9.5 \\
\hline MK-9(- $\left.\mathrm{H}_{2}\right)$ & 33.3 & 69.3 & 9.1 & 19.3 & 30.9 & 73.3 \\
\hline Other MKs & 14.3 & 10.6 & 13.9 & 5.2 & 14.5 & 8.9 \\
\hline
\end{tabular}

\section{Relationships between quinone profiles and RFLP pat- terns}

The foregoing results indicated that the scum formation in activated sludge studied here was caused by two different species of actinomycetes, Gordona amarae and Rhodococcus sp. Members of the genera Gordona and Rhodococcus are distinguishable in menaquinone types; that is, the predominant menaquinones are $\mathrm{MK}-9\left(\mathrm{H}_{2}\right)$ in the former and $\mathrm{MK}-8\left(\mathrm{H}_{2}\right)$ in the latter ${ }^{13,14,26,48)}$. Taking advantage of this, we also attempted to identify the dominant bacteria of the scum samples by quinone profiling. As shown in Table 3, the major menaquinones detected were MK-9 $\left(\mathrm{H}_{2}\right)$ in scum A and C and MK-8 $\left(\mathrm{H}_{2}\right)$ in scum B, supporting the results obtained with the $16 \mathrm{~S}$ rDNA clones.

The results of quinone profiling also revealed that about half of the quinone contents of the raw scum samples constituted ubiquinones, suggesting the abundant occurrence of ubiquinone-producing bacteria as "contaminants". Repeated washing of the scum resulted in a marked increase in the MK-8 $\left(\mathrm{H}_{2}\right)$ or MK- $9\left(\mathrm{H}_{2}\right)$ content with concomitant reduction of ubiquinones.

\section{Discussion}

Previous studies have shown that HPLC provides higher resolution for the separation of PCR products than does conventional agarose gel electrophore$\mathrm{sis}^{2,55)}$. In the present study, we applied the anion-exchange HPLC method to the RFLP analysis of PCR- amplified 16S rDNA and confirmed the high resolution of this method. The HPLC system allowed for separation of DNA fragments with a size difference of 5 and $15 \mathrm{bp}$ in a molecular mass range up to 200 and $500 \mathrm{bp}$, respectively. These results indicate that the HPLC method is useful in particular for the separation of small DNA fragments of less than $500 \mathrm{bp}$. Although the sensitivity of the HPLC system used here is not so high due to the use of a spectrophotometric detector at $260 \mathrm{~nm}$, this system is superior to agarose gel electrophoresis with ethidium bromide detection in detecting signals of small DNA fragments. The HPLC method is rapid, as it takes only $20 \mathrm{~min}$ in a run of one sample. However, it requires more time for analysis than multi-lane gel electrophoresis when applied for large numbers of samples. An overnight analysis with an autosampler may solve this problem to some extent.

It has been previously shown that tandem tetrameric endonucleases are suitable for 16S rDNARFLP analysis for the identification and classification of microorganisms ${ }^{19,21,36)}$. In this study we used three tetrameric enzymes, HaeIII, HhaI, and MspI, and one hexameric enzyme, SmaI, for the RFLP analysis. Our findings indicate that the RFLP profiles with only one of these restriction enzymes have limitations in the identification of Gordona and Rhodococcus species, whereas a combined use of the profiles with all these tetrameric enzymes is useful for this purpose (Table 2). The phylogenetic analysis of $16 \mathrm{~S}$ rDNA-RFLP profiles showed that there was a similarity in branching patterns between the phylogenetic trees based on the RFLP data and 16S rDNA sequences themselves. This finding indicates that 16S rDNA-RFLP patterns not only provide criteria of value in the identification of scum-forming bacteria but also have phylogenetic significance.

Scum formation in activated sludge plants has been reported to be associated with massive growth of $G$. amarae or some other species of nocardioform actinomycetes ${ }^{3-6,10,16,25,30,31,35,39,40,46)}$. The 16S rDNA clones of the three scum samples studied here were classified into two groups with respect to RFLP patterns. One of the groups, which included the two test samples, exhibited RFLP patterns that were almost 
identical with the RFLP profiles of $G$. amarae. The remaining group showed RFLP patterns that did not correspond to profiles of any reference organisms, but appeared to belong to a member of the genus Rhodococcus. These observations were supported by the results of quinone profiling of the scum samples. Our results support the general agreement that scum formation is caused mainly by $G$. amarae with other actinomycetes involved in some cases. A recent hybridization study with group-specific rRNA probes for foaming activated sludge showed that the foaming problem in a wastewater treatment was linked to Gordona strains other than $G$. amarae ${ }^{9}$.

In this study PCR-aided 16S rDNA clone libraries were constructed from the bulk DNA of the scum. Almost all clones isolated from the same sample gave identical RFLP patterns probably due to the overwhelming majority of one species of the nocardioform actinomycetes in the scum samples examined. In fact, there was no difference in the RFLP patterns between the 16S rDNA amplified directly from the scum lysate and the major $16 \mathrm{~S}$ rDNA clones therefrom. As shown by quinone profiling, repeated washing of the scum is effective in increasing the purity of the "true" scumforming bacteria. Therefore, it may be possible to identify the predominant bacteria in the scum by direct RFLP profiling of 16S rDNA amplified from the scum lysate, as long as the scum sample is well washed prior to the analysis.

In conclusion, the PCR-RFLP analysis of $16 \mathrm{~S}$ rDNA is a rapid and reliable method for the identification of scum-forming bacteria without the need for isolation and cultivation. Moreover, a combination of 16S rDNA-RFLP analysis and quinone profiling should provide a more powerful non-cultivating tool for the identification of the scum-forming bacteria in activated sludge plants.

\section{References}

1) Anonymous. 1969. Milwaukee mystery: unusual operating problem develops. Water Sew. Works 116: 213.

2) Asakawa, J., C. Satoh, Y. Yamasaki and S. -H. Chen. 1992. Accurate and rapid detection of heterozygous carriers of a deletion by combined poly- merase chain reaction and high-performance liquid chromatography. Proc. Natl. Acad. Sci. USA 89: 9126-9130.

3) Blackall, L. L., A. E. Harbers, P. F. Greenfield and A. C. Hayward. 1988. Actinomycete scum problems in Australian activated sludge plants. Water Sci. Technol. 20: 493-495.

4) Blackall, L. L., J. H. Parlett, A. C. Hayward, D. E. Minnikin, P. F. Greenfield and A. E. Harbers. 1989. Nocardia pinensis sp. nov., an actinomycete found in activated sludge foams in Australia. J. Gen. Microbiol. 135: 1547-1558.

5) Blackall, L. L., E. M. Seviour, M. A. Cunningham, R. J. Seviour and P. Hugenholz. 1994. "Microthrix parvicella" is a novel, deep branching member of the actinomycetes subphylum. Syst. Appl. Microbiol. 17: 513-518.

6) Blackall, L. L., H. Stratton, D. Bradford, T. D. Dot, C. Sjörup, E. M. Seviour and R. J. Seviour. 1996. “Candidatus Microthrix parvicella,'” a filamentous bacterium from activated sludge sewage treatment plants. Int. J. Syst. Bacteriol. 46: 344-346.

7) Bond, P. L., P. Hugenholz, J. Keller and L. L. Blackall. 1995. Bacterial community structures of phosphate-removing and non-removing activated sludge from sequencing batch reactors. Appl. Environ. Microbiol. 61: 1910-1916.

8) Brosius, J., J. L. Palmer, J. P. Kennedy and H. F. Noller. 1978. Complete nucleotide sequence of a 16S ribosomal RNA gene from Escherichia coli. Proc. Natl. Acad. Sci. USA 75: 4801-4805.

9) De Los Reyes, F. L., W. Ritter and L. Raskin. 1997. Group-specific small-subunit rRNA hybridization probes to characterize filamentous foaming in activated sludge. Appl. Environ. Microbiol. 63: 1107-1117.

10) Dhaliwal, B. S. 1979. Nocadia amarae and activated sludge foarming. J. Water Pollut. Control Fed. 51: 628-350.

11) Felsenstein, J. 1985. Confidence limits on phylogenies: an approach using the bootstrap. Evolution 39: 783-791.

12) Fujita, M. 1996. Control of nuisance microbes in sewage treatment processes (in Japanese). Jpn. J. Water Treat. Biol. 32: 143-148.

13) Goodfellow, M., J. Chun, S. Stubbs and A. S. Tobili. 1994. Transfer of Nocardia amarae Lechevalier and Lechevalier 1974 to the genus Gordona as Gordona amarae comb. nov. Lett. Appl. Microbiol. 19: 401 405.

14) Goodfellow, M., D. E. Minnikin, C. Todd, G. Alderson, S. M. Minnikin and M. D. Collins. 1982. Numerical and chemical classification of Nocardia amarae. J. Gen. Microbiol. 128:1283-1297.

15) Gurtler, V., V. A. Wilson and B. C. Mayall. 1991. 
Classification of medically important clostridia using restriction endonuclease site differences of PCRamplified 16S rDNA. J. Gen. Microbiol. 137: 2673-2679.

16) Hart, M. A. 1985. Scum formation in a nutrient removing activated sludge plant. Water S. A. 11: 171-178.

17) Hiraishi, A. 1988. Respiratory quinone profiles as tools for identifying different bacterial populations in activated sludge. J. Gen. Appl. Microbiol. 34: 39-56.

18) Hiraishi, A. 1989. Isoprenoid quinone profiles for identifying and classifying microorganisms in the environment, In Recent advances in microbial ecology, ed. by Hattori, T., Ishida, Y., Maruyama, Y. Morita, R. Y. and Uchida, A., Japan Scientific Societies Press, Tokyo, p. 663-668.

19) Hiraishi, A., Y. Kamagata and K. Nakamura. 1995. Polymerase chain reaction amplification and restriction fragment length polymorphism analysis of $16 \mathrm{~S}$ rRNA genes from methanogens. J. Ferment. Bioeng. 79: 523-529.

20) Hiraishi, A. and K. Komagata. 1989. Effects of the growth medium composition on menaquinone homolog formation in Micrococcus luteus. J. Gen. Appl. Microbiol. 35: 311-318.

21) Hiraishi, A., K. Muramatsu and Y. Ueda. 1996. Molecular genetic analyses of Rhodobacter azotoformans sp. nov. and related species of phototrophic bacteria. Syst. Appl. Microbiol. 19: 168-177.

22) Hiraishi, A., Y. K. Shin, Y. Ueda and J. Sugiyama. 1994. Automated sequencing of PCR-amplified 16S rDNA on "Hydrolink"' gels. J. Microbiol. Methods 19: $145-154$.

23) Hiraishi, A., Y. Ueda, J. Ishihara and T. Mori. 1996. Comparative lipoquinone analysis of influent sewage and activated sludge by high-performance liquid chromatography and photodiode array detection. J. Gen. Appl. Microbiol. 42: 457-469.

24) Holton, T. A. and M. W. Graham. 1991. A simple and efficient method for direct cloning of PCR products using ddT-tailed vectors. Nucleic Acids Res. 19:1156.

25) Khan, A. R. and C. F. Foster. 1991. Aspects of the nutrition and the growth of Rhodococcus rubra in relation to the formation of stable foams. Environ. Technol. 23: 271-277.

26) Klatte, S., F. A. Rainey and R. M. Kroppenstedt. 1994. Transfer of Rhodococcus aichiensis Tsukamura 1982 and Nocardia amarae Lechevalier and Lechevalier 1974 to the genus Gordona as Gordona aichiensis comb. nov. and Gordona amarae comb. nov. Int. J. Syst. Bacteriol. 44: 769-773.

27) Kusukawa, N., T. Uemori, K. Asada and I. Kato. 1990. Rapid and reliable protocol for direct sequencing of material amplified by the polymerase chain reaction. BioTechniques 9:66-72.

28) Laguerre, G., M. -R. Allard, F. Revoy and N. Amarger. 1994. Rapid identification of rhizobia by restriction fragment length polymorphism analysis of PCR-amplified 16S rRNA genes. Appl. Environ. Microbiol. 60: 56-63.

29) Lane, D. J. 1991. 16S/23S rRNA sequencing, In Nucleic acid techniques in Bacterial systematics, ed. by Stackebrandt, E. and M. Goodfellow., John Wiley \& Sons, Chichester, p. 115-175.

30) Lechevalier, M. P. and H. A. Lechevalier. 1974. Nocardia amarae sp. nov., an actinomycete common in foaming activated sludge. Int. J. Syst. Bacteriol. 24: 278-288.

31) Lemmer, H. and R. M. Kroppenstedt. 1984. Chemotaxonomy and physiology of some actinomycetes isolated from scumming activated sludge. Syst. Appl. Microbiol. 5: 124-135.

32) Maidak, B, L., G. J. Olsen, N. Larsen, R. Overbeek, M. J. McCaughey and C. R. Woese, 1997. The RDP (Ribosomal Database Project). Nucleic Acids Res. 25: 109-110.

33) Marchuk, D., M. Drumm, A. Saulino and F. S. Collins. 1991. Construction of T-vectors, a rapid and general system for direct cloning of unmodified PCR products. Nucleic Acids Res. 19: 1154.

34) Marmur, J. 1961. A procedure for the isolation of deoxyribonucleic acid from micro-organisms. J. Mol. Biol. 3: 208-218.

35) Mori, T., Y. Sakai, K. Honda, I. Yano and S. Hashimoto. 1988. Stable abnormal foam in activated sludge process produced by Rhodococcus sp. with strong hyddrophobic property. Environ. Technol. Lett. 9: 1041-1048.

36) Moyer, C. L., F. C. Dobbs and D. M. Karl. 1994. Estimation of diversity and community structure through restriction fragment length polymorphism distribution analysis of bacterial 16S rRNA genes from a microbial mat at an active, hydrothermal vent system, Loihi Seamount, Hawaii. Appl. Environ. Microbiol. 60: 871-879.

37) Nesme, X., M. Vaneechoutte, S. Orso, B. Hoste and J. Swings. 1995. Diversity and genetic relatedness within genera Xanthomonas and Stenotrophomonas using restriction endonuclease site differences of PCR-amplified 16S rRNA gene. Syst. Appl. Microbiol. 18: 127-135.

38) Page, R. D. M. 1996. TreeView version 1.0. University of Glasgow, U. K.

39) Pipes, W. O. 1978. Actinomycete scum production in activated sludge processes. J. Water Pollut. Control. Fed. 50: 528-634.

40) Pitt, P. and D. Jenkins. 1990. Causes and control of Nocardia in activated sludge. Res. J. Water Pollut. Control. Fed. 62: 143-150.

41) Ralph, D., M. McClelland, J. Welsh, G. Baranton 
and P. Perolat. 1993. Leptospira species categorized by arbitrarily primed polymerase chain reaction (PCR) and by mapped restriction polymorphism in PCR-amplified rRNA genes. J. Bacteriol. 175: 973-981.

42) Ruimy R., P. Boiron, V. Biovin and R. Christen. 1994. A phylogeny of the genus Nocardia deduced from the analysis of small-subunit ribosomal DNA sequences, including transfer of Nocardia amarae to the genus Gordona as Gordona amarae comb. nov. FEMS Microbiol. Lett. 123:261-268.

43) Saitou N. and M. Nei. 1987. The neighbor-joining method: a new method for reconstructing phylogenetic trees. Mol. Biol. Evol. 4: 406-425.

44) Sambrook J., E. F. Fritsch and T. Maniatis. 1989. In Molecular Cloning, A Laboratory Manual, 2nd. ed., Cold Spring Harbor Laboratory Press, New York.

45) Schneider, B., U. Ahrens, B. C. Kirkpatrick and E. Seemuller. 1993. Classification of plant-pathogenic mycoplasma-like organisms using restriction-site analysis of PCR-amplified 16S rDNA. J. Gen. Microbiol. 139: 519-527.

46) Sezgin, M. , M. P. Lechevalier and P. R. Karr. 1988. Isolation and identification of actinomycetes present in activated sludge scum. Water Sci. Technol. 20: 257-263.

47) Shuppler, M., F. Mertens, G. Shön and U. B. Göbel. 1995. Molecular characterization of nocardioform actinomycetes in activated sludge by $16 \mathrm{~S}$ rRNA analysis. Microbiology 141:513-521.

48) Stackebrandt, E., J. Smida and M. D. Collins. 1988. Evidence of phylogenetic heterogeneity within the genus Rhodococcus: revival of the genus Grodona (Tsukamura). J. Gen. Appl. Microbiol.
34: 341-348.

49) Takeuchi, J. 1992. Sludge scumming by nocardioform actinomycetes. (1) Taxonomy of causative micro-organisms (in Japanease). Yosui to Haisui (Water \& Wastes) 34: 467-476.

50) Takeuchi, J. 1992. Sludge scumming by nocardioform actinomycetes. (2) Physiology and ecology of causative micro-organisms (in Japanease). Yosui to Haisui (Water \& Wastes) 34: 562-572.

51) Takeuchi, J. 1992. Sludge scumming by nocardioform actinomycetes. (3) Methodology for causative micro-organisms (in Japanease). Yosui to Haisui (Water \& Wastes) 34: 727-738.

52) Thompson, J. D., D. G. Higgins and T. J. Gibson. 1994. CLUSTAL W: improving the sensitivity of progressive multiple sequence alignment through sequence weighting, position-specific gap penalties and weight matrix choice. Nucleic Acids Res. 22: 4673-4680.

53) Urakawa, H., K. Kita-Tsukamoto and K. Ohwada. 16S rDNA genotyping using PCR/RFLP (restriction fragment length polymorphism) analysis among the family Vibrionaceae. FEMS Microbiol. Lett., 152: 125-132.

54) Vaneechouttee, M., R. Rossau, F. De Vos, M. Gillis, D. Janssens, N. Paepe, A. De Rouck, T. Fiers, G. Claeys and K. Kersters. 1992. Rapid identification of bacteria of the Comamonadaceae with amplified ribosomal DNA-restriction analysis (ARDRA). FEMS Microbiol. Lett. 93: 227-234.

55) Zeillinger, R., C. Schneeberger, P. Speiser and F. Kury. 1993. Rapid quantitative analysis of differential PCR products by high-performance liquid chromatography. BioTechniques 15: 89-95. 